
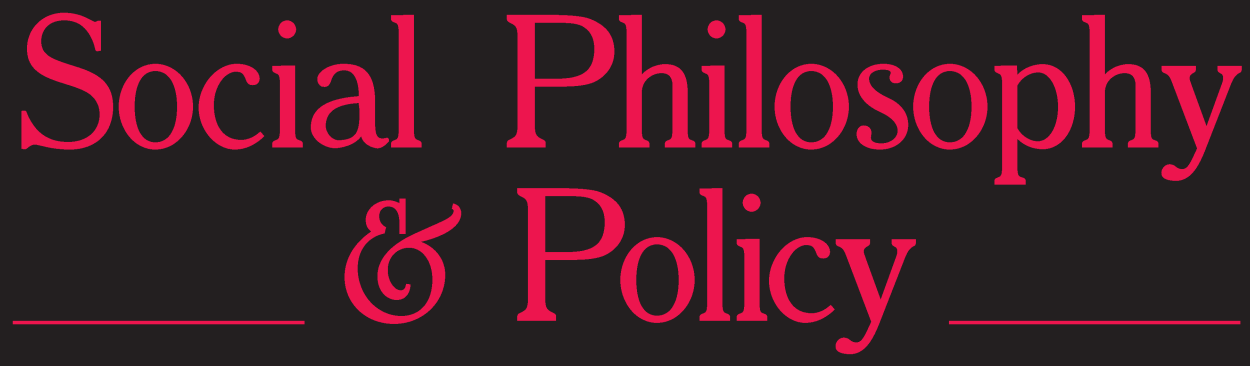

\title{
Liberalism and Capitalism
}

\section{CONTENTS}

ALAN CHARLES KORS The Paradox of John Stuart Mill 1

SAMUEL FREEMAN Capitalism in the Classical and High

Liberal Traditions

RONALD J. PESTRITTO Founding Liberalism, Progressive

Liberalism, and the Rights of Property

GERALD GAUS

The Property Equilibrium in a Liberal

Social Order (or How to Correct Our Moral Vision)

MICHAEL P. ZUCKERT Judicial Liberalism and Capitalism: Justice Field Reconsidered

LOREN E. LOMASKY Liberty After Lehman Brothers

DANIEL M. HAUSMAN

A Lockean Argument for Universal Access to Health Care

MICHAEL C. MUNGER Euvoluntary or Not, Exchange Is Just

TYLER COWEN

Rule Consequentialism Makes Sense After All

RICHARD J. ARNESON Liberalism, Capitalism, and "Socialist"

Principles

N. SCOTT ARNOLD

Are Modern American Liberals Socialists or Social Democrats? 


\section{Social Philosophy \& Policy}

ISSN 0265-0525

Editor: Ellen Frankel Paul

Associate Editors: Fred D. Miller, Jr., and Jeffrey Paul

Managing Editors: Harry Dolan and Pamela Phillips

Administrative Editor: Tamara Sharp

Social Philosophy and Policy Center

David Braybrooke

University of Texas, Austin

Baruch Brody

Rice University

Allen Buchanan

Duke University

James M. Buchanan

Center for Study of Public Choice,

George Mason University

Jules Coleman

Yale Law School

Jack Douglas

University of California, San Diego

Richard A. Epstein

University of Chicago Law School

\section{Editorial Board}

James Fishkin
Stanford University
Martin Golding
Duke University
John Gray
London School of Economics and
Political Science
Gilbert Harman
Princeton University
Eric Mack
Tulane University
Harvey Mansfield, Jr.
Harvard University
Wallace I. Matson
University of California, Berkeley

Jan Narveson

University of Waterloo

Nicholas Rescher

University of Pittsburgh

David Sidorsky

Columbia University

Hillel Steiner

University of Manchester

James Q. Wilson

Pepperdine University,

Malibu

Leland B. Yeager

Auburn University

Social Philosophy \& Policy is an interdisciplinary journal with an emphasis on the philosophical underpinnings of enduring social policy debates. Each issue is dedicated to a particular theme chosen by the editors, with the advice of the editorial board, designed to appeal to both academic specialists and a broader scholarly audience. While not primarily a journal of policy prescriptions, several contributions to each issue will typically connect theory with practice. The editors encourage and actively pursue diversity of viewpoints of contributors. Diversity is also encouraged by selecting authors from among different disciplines, especially philosophy, economics, political science, and the law. Readers' suggestions for future themes are always welcome, as are inquiries about the topics of issues already planned.

Editorial Office: Social Philosophy and Policy Center, Bowling Green State University, Bowling Green, OH 43403-0188, USA.

Publishing, Subscription, and Advertising Information: See inside back cover. Copyright (C) 2011 Social Philosophy and Policy Foundation

All rights reserved. No part of this publication may be reproduced, in any form or by any means, electronic, photocopying or otherwise, without permission in writing from Social Philosophy \& Policy. Photocopying information for users in the USA: The Item-Fee Code for this publication (0265-0525/11 \$15.00) indicates that copying for internal or personal use beyond that permitted by Sec. 107 or 108 of the U.S. Copyright Law is authorized for users duly registered with the Copyright Clearance Center (CCC) Transaction Reporting Service, provided that the appropriate remittance is paid directly to: CCC, 222 Rosewood Drive, Danvers, MA 01923. Specific written permission must be obtained from Social Philosophy \& Policy for all other copying. 


\section{CONTRIBUTORS}

Alan Charles Kors is Henry Charles Lea Professor of European History at the University of Pennsylvania. He received his Ph.D. in European History from Harvard University. He has published several books and many articles on early-modern French intellectual history, and was editorin-chief of the four-volume Encyclopedia of the Enlightenment (2002). A member of the National Council for the Humanities, he has received fellowships from the American Council for Learned Societies, the SmithRichardson Foundation, and the Davis Center for Historical Studies at Princeton University. In 2003-2004, he was a Phi Beta Kappa Visiting Scholar, lecturing nationally on intellectual history and on academic freedom. In 2005, he received the National Humanities Medal.

Samuel Freeman is Avalon Professor of the Humanities and Professor of Philosophy and Law at the University of Pennsylvania. He is the author of two books, Justice and the Social Contract (2006) and Rawls (2007). He edited John Rawls's Collected Papers (1999) and his Lectures on the History of Political Philosophy (2007). In addition, he edited The Cambridge Companion to Rawls (2003) and (with R. J. Wallace and Rahul Kumar) Reasons and Recognition: Essays on the Philosophy of T. M. Scanlon (2011).

Ronald J. Pestritto is Charles and Lucia Shipley Chair in the American Constitution and Associate Professor of Politics at Hillsdale College, where he teaches political philosophy, American political thought, and American politics. He is Senior Fellow of the College's Kirby Center for Constitutional Studies and Citizenship and Senior Fellow of the Claremont Institute for the Study of Statesmanship and Political Philosophy. He has published seven books, including Woodrow Wilson and the Roots of Modern Liberalism (2005) and American Progressivism (2008). Among his other books are an edited collection of Wilson's speeches and writings entitled Woodrow Wilson: The Essential Political Writings (2005), a three-book series on American political thought, and Founding the Criminal Law: Punishment and Political Thought in the Origins of America (2000).

Gerald Gaus is James E. Rogers Professor of Philosophy at the University of Arizona, where he directs the program in Philosophy, Politics, Economics, and Law. Among his books are On Philosophy, Politics, and Economics (2008), Justificatory Liberalism (1996), and Value and Justification (1990). His most recent book is The Order of Public Reason: A Theory of Freedom and Morality in a Diverse and Bounded World (2010). Currently he and Julian Lamont are writing a book entitled Economic Justice, and with Fred 
D'Agostino he is editing the Routledge Companion to Social and Political Philosophy.

Michael P. Zuckert is Nancy R. Dreux Professor of Political Science at the University of Notre Dame. He has written extensively on the liberal tradition in political philosophy and American constitutionalism. He is the author of several books, including The Natural Rights Republic (1996), Launching Liberalism: John Locke and the Liberal Tradition (2002), and, most recently, Natural Rights and American Constitutionalism (2011).

Loren E. Lomasky is Cory Professor of Political Philosophy, Policy, and Law at the University of Virginia, where he directs the Philosophy, Politics, and Law program. He previously taught at Bowling Green State University and the University of Minnesota, Duluth, and has held visiting positions at Virginia Polytechnic Institute, Australian National University, the Australian Defence Force Academy, and the National University of Singapore. He is the author of Persons, Rights, and the Moral Community (1987), for which he was awarded the 1990 Matchette Prize. With Geoffrey Brennan he coauthored Democracy and Decision: The Pure Theory of Electoral Preference (1993) and coedited Politics and Process: New Essays in Democratic Theory (1989).

Daniel M. Hausman is Herbert A. Simon Professor of Philosophy at the University of Wisconsin-Madison and a member of the American Academy of Arts and Sciences. He is the author of Capital Profits and Prices (1981), The Inexact and Separate Science of Economics (1992), Causal Asymmetries (1998), and, with Michael McPherson, Economic Analysis, Moral Philosophy, and Public Policy (second edition, 2006). He has published more than 150 essays and reviews and is a cofounder, with Michael McPherson, of the journal Economics and Philosophy. His most recent research focuses on philosophical questions concerning generic health measurement, and he is currently completing a book on preferences, as they are understood in economics, philosophy, psychology, and everyday life.

Michael C. Munger is Professor of Political Science, Public Policy, and Economics at Duke University, where he served as chair of the Political Science Department for ten years. He directs Duke's Philosophy, Politics, and Economics program, working with Geoffrey Sayre-McCord at the University of North Carolina to run the joint program. He received his Ph.D. in Economics from Washington University in St. Louis in 1984.

Tyler Cowen is Holbert C. Harris Professor of Economics at George Mason University and is General Director of both the Mercatus Center and the James M. Buchanan Center for Political Economy. He is the author of numerous books, including, most recently, The Age of the Infovore: Succeed- 
ing in the Information Economy (2010). In addition to his work in economics, he has also published in philosophy journals, including Ethics and Philosophy and Public Affairs. He cowrites with Alex Tabarrok the blog Marginal Revolution at www.marginalrevolution.com.

Richard J. Arneson is Distinguished Professor of Philosophy at the University of California, San Diego. He has published more than a hundred essays on moral and political philosophy. Most of his work is on topics in the theory of justice. He has recently published essays on Lockean libertarianism, on the justification of democracy, and on the interpretation and defense of luck-egalitarian approaches to distributive justice.

N. Scott Arnold is Professor of Philosophy at the University of Alabama at Birmingham, where he has taught since 1982. During 1991-1992, he was a Title VIII Fellow at the Hoover Institution on War, Revolution, and Peace, and he returned there as a Visiting Scholar in the summer of 1999. He is the author of Marx's Radical Critique of Capitalist Society (1990) and The Philosophy and Economics of Market Socialism (1994), and is the coeditor (with Theodore M. Benditt and George Graham) of Philosophy Then and Now (1998). 


\section{ACKNOWLEDGMENT}

The editors gratefully acknowledge Liberty Fund, Inc., for holding the conference at which the original versions of many of these papers were presented and discussed. 